DOI:

\title{
Effect of Electrode Material on The Removal of Industrial Oil and Soap Wastewater Using Electrocoagulation Process
}

\author{
Mostafa S. Mohammed ${ }^{1,3,}$ *, Abdelaziz E. Abdelaziz ${ }^{1}$, \\ Ragab M. EI Shehawy ${ }^{2}$, and Hafez A. Afify ${ }^{1}$ \\ ${ }^{1}$ Departments of Public Works, Faculty of Eng., Tanta University, Egypt \\ ${ }^{2}$ Department of Public Works, Faculty of Engineering, Mansoura University, Egypt \\ ${ }^{3}$ Department of Civil Eng., High Delta Institute of Engineering and Technology \\ *(Corresponding author: mostafasallam52@yahoo.com)
}

\begin{abstract}
Treatment of oil and soap industrial wastewater using aluminum and iron electrode material has been investigated in this study to compare for each electrode, the performance of the electrocoagulation process. The effectiveness of relevant industrial wastewater characteristics such as the chemical oxygen demand (COD) and oil-grease removal effects of major operating parameters such as medium $\mathrm{pH}$ value, electrode material, and current density, and running time and energy consumption were studied. All experiments were done in an electrocoagulation cell with an effective volume of $500 \mathrm{mg} /$ liters. Under the same operating conditions, it was observed that aluminum electrodes have higher efficiency of removal than iron electrodes. COD and O\&G removal efficiencies of $94.93 \%, 90.20 \%$ and $27.49 \%, 13.27 \%$ were observed for aluminum and iron electrode in a special case with optimum initial $\mathrm{pH}$ value, maximum current density, time, and initial COD concentration equal to $3,73.33 \mathrm{~A} / \mathrm{m}^{2}, 30 \mathrm{~min}, 19750 \mathrm{mg} / \mathrm{l}$, respectively. The electrode energy consumptions for each electrode material have been calculated to be 1.68, 3.04 $\mathrm{KWh} / \mathrm{kg}$ COD for Aluminum and iron respectively at 15 volts. It can be concluded that the electrocoagulation process using aluminum electrodes is efficient for COD and $O \& G$ removal from industrial wastewater.
\end{abstract}

Keywords: Electrocoagulation; COD; Iron electrodes; aluminum electrodes; Oil-Soup industrial wastewater.

\section{Introduction}

One of the world's most important materials for hydrocarbons is oil [1-2]. In different stages of development, shipping, processing, and usage, oils may be released into the atmosphere. Carbon refineries, petrochemical, metal-refining, refining and finishing, food manufacturing, garment, and leather are significant industrial sources of oily wastewater [3]. Oily wastes could also come from public outlets, like kitchens and garbage [4]. Oil, lubricants, cutting fluids, tars, grates, raw oils, diesel oils, kerosene, gasoline, and so on can contain oils from polluted water [5]. Over the last decades, a lot of oily wastewater is created from various sources with the rapid growth of industry and urban development [6]. The recovery of oil from drainage is considered a significant problem in the area of care. Dispersed oil droplets typically have a large surface load, which ensures that the oil-in-water mechanism stabilizes. It is especially valid in the case of emulsified crude. Mechanical agitation and application of emulsifying agents typically accomplish emulsion production and stabilization. While in certain effluent sources consistency and quantity of oil wastes vary, substantial portions of oil are still present in the emulsified form [7]. Other accessible techniques have been used for oil removal including gravity isolation, cyclone isolation, and precipitation of chemical materials, sorption, membranes, and oxidation [8-910-11-12]. Although there have been many benefits of these techniques, there are also unique drawbacks of treatment systems (i.e. poor efficiencies, extended turnaround period, secondary emissions, and high cost). The performance of certain oily wastewater treatment systems remains unsatisfactory. Electrocoagulation is an alternative to existing oil removal technologies. This process leads to the formation of hydrolysis products (hydroxo-metal species) that are effective for destabilizing the pollutants by electrifying the sacrificial aides generally of aluminum or iron to the wastewater [1314-15]. There are other benefits for the usage of 
electrocoagulation such as easy tools, simplicity of use, fewer treatment time, fewer additives, and lower sludge material [16]. Electrocoagulation separating oil from the wastewater is a complex process involving different chemical and physical processes that are regulated by electrochemical, physical, and hydro-dynamic parameters in a lumped result [17]. Electrocoagulation (EC) is a flexible method of treating water and wastewater based on the electrochemical dissolution into soluble and insoluble species of sacrificial metal (usually aluminum or iron) as shown in Figure (1), which enhances soluble or colloidal pollutants coagulation, adsorption, or precipitation [18]. As a result of incremental in situ formulations of coagulants, EC varies greatly from conventionally chemical coagulants (CC) in which the anode is added at once using a set current or cell potential.

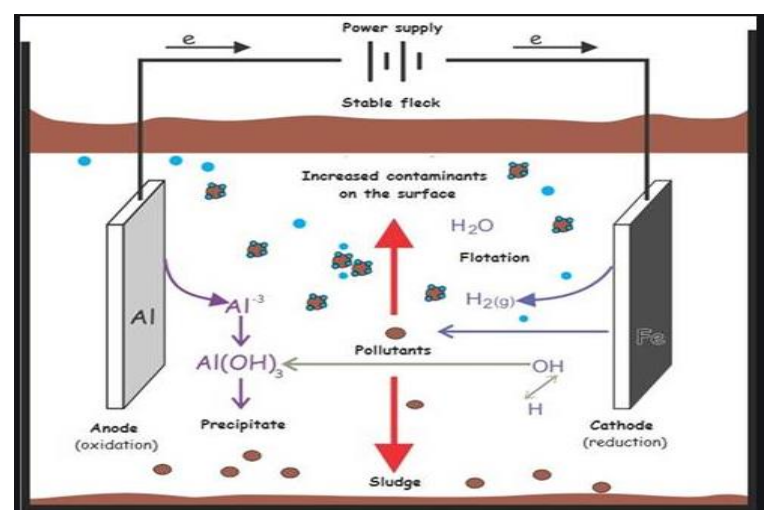

Figure 1- Mechanism of Electrocoagulation

Metal dissolution (anode) and water reduction are electrolyte reactions in $\mathrm{EC}$ with $\mathrm{Al}$ electrodes. (Cathode):

$$
\begin{aligned}
& A L_{(s)} \rightarrow A L_{(a q)}^{3+}+3 e^{-} \\
& 2 \mathrm{H}_{2} \mathrm{O}+2 e^{-} \rightarrow H_{2(g)}+2 O H_{(a q)}^{-}
\end{aligned}
$$

For the electrodes of iron, Equ (2) prevails at the cathode and it is widely agreed that oxidation of anodic $\mathrm{Fe}(\mathrm{s})$ is first confined to $\mathrm{Fe}$ (II) cations:

$$
\mathrm{Fe}_{(s)} \rightarrow \mathrm{Fe}_{(a q)}^{2+}+2 e^{-}
$$

$\mathrm{Fe}$ (III) cations are therefore believed, while alternate methods have been proposed [21], to be produced from the oxidation of $\mathrm{Fe}$ (II) in electrons or bulk with dissolute oxygen or pollutants [19-20]. Additional potential anodic responses include oxidation of water.

$$
2 \mathrm{H}_{2} \mathrm{O} \rightarrow \mathrm{O}_{2(g)}+4 \mathrm{H}_{(a q)}^{+}+4 e^{-}
$$

And their $\mathrm{Cl}_{2}(\mathrm{~g})$ oxidation in acidic or $\mathrm{ClO}$ - anions in alkaline water in the presence of chlorine anions
[24]. Both of these reactions depend on the $\mathrm{pH}$ value. With the hydroxide anion reaction of the electro generated cations due to the evolution of hydrogen at the cathode, Al (III) cations will eventually form soluble monomeric hydroxides or oxyhydroxides. which, when $\mathrm{pH}$ value is between 6 and 8 , polymerize into insoluble $\mathrm{AL}(\mathrm{OH})_{3(\mathrm{~s})}$ [21-23]. The same happens to iron electrodes but the $\mathrm{Fe}(\mathrm{OH})_{3(\mathrm{~s})}$ insoluble hydroxide is stable from $\mathrm{pH}$ value 5 to $\mathrm{pH}$ value 10 [21-22].

Specific agricultural treatment [25], industrial [2627], oil wastes treatment, with removal efficiencies as high as 99\% [28], restaurant wastewater [29], fluoride [30], and municipal wastewater treatment [31], as well as water potabilization [24-32] has been effectively introduced with electrocoagulation. Also, EC can eliminate a wide range of contaminants, including heavy metals [21-12].

The objective of this study is to compare the performance of the electrocoagulation process using aluminum and iron electrodes for COD and oil and grease removal from solution; and to evaluate the effects of operational variables of initial COD concentration, electrocoagulation time, and $\mathrm{pH}$ value, and voltage density towards the removal of COD and $\mathrm{O} \& \mathrm{G}$ industrial wastewater from the solution.

\section{Experimental Studies}

\section{1 and MaterialsMethods}

The electrocoagulation unit was comprised of a 500 $\mathrm{mL}$ Beaker of the electrochemical cell and two plates of the same type of metal with a size of $(5 \mathrm{~cm} \times 15 \mathrm{~cm}$ $\times 0.2 \mathrm{~cm}$ ) as electrodes (aluminum or iron) as illustrated in Figure (2).

Figure (3) indicates the image of aluminum and iron plate electrode used in this study. The gap between the electrodes (d) $1.5 \mathrm{~cm}$ except for the indication.

At ambient temperature, experimental studies were operated in many modes. During experimental runs of $30 \mathrm{~min}$, the samples were taken at certain times. Upon centrifugation, the COD of the samples was measured using the normal Water and Wastewater Methods [33].

Oil-grease was determined with hexane extraction. The $\mathrm{pH}$ value and conductivity were adjusted to a desirable value using $\mathrm{NaOH}$ or $\mathrm{H}_{2} \mathrm{SO}_{4}$, and $\mathrm{NaCl}$, and measured by THE EXTECH341350A digital benchtop $\mathrm{pH}$ meter and a Lutron CD-4303 model conductivity meter, respectively. The schematic diagram of the experimental setup has shown in Figure (2). 


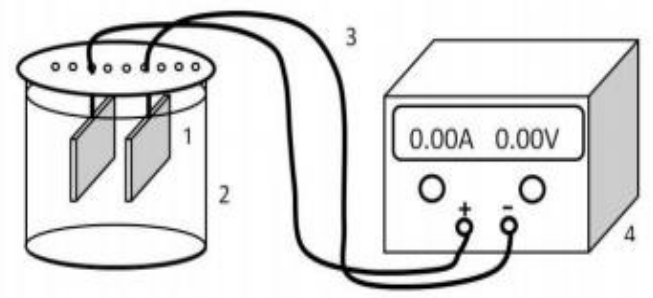

Figure 2- Schematic diagram of electrocoagulation cell with DC power supply and two electrodes Indicators

1. Electrodes plates (both aluminum and both iron)

2. Plexiglass beaker reactor (electrochemical cell)

3. Copper wire

4. Digital D.C. Power Supply
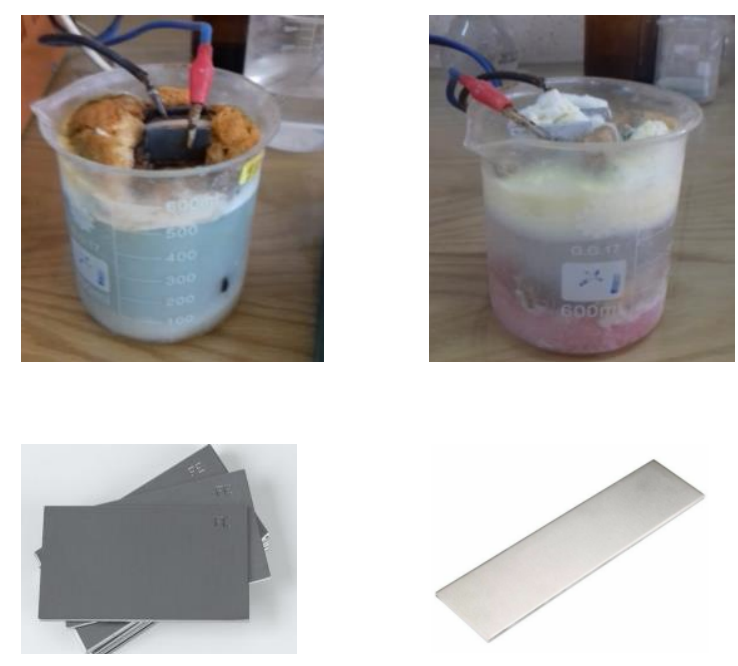

Figure 3- Aluminum plate electrode and iron plate electrode

At the beginning of each experiment, $500 \mathrm{~mL}$ of industrial oil and soap wastewater was fed into the electrocoagulation cell and a certain amount of current was applied to the circuit for $30 \mathrm{~min}$. The number of voltage densities that have been applied to the system was $5,10,15,20,25$ volts, and $\mathrm{pH}$ value change from 3 to 11 all experiment was carried out at room temperature. Experimental samples were taken for measurement at the specific intervals of each run. Industrial samples of wastewater were obtained from an exhaust oil-soap mixed tank solution at an oil and soap factory located at EL-Dakahlia Governorate, Egypt. The industrial oil and soap wastewater were fully characterized, as shown in table (1).
Table 1- Characteristics of oil and soap industrial wastewater

\begin{tabular}{|l|c|}
\hline \multicolumn{1}{|c|}{ Parameter } & Concentration \\
\hline $\mathrm{pH}$ value & 11.95 \\
\hline Conductivity & 4110 \\
\hline Total dissolved solids & 2800 \\
\hline COD & $19750 \mathrm{mg} / \mathrm{l}$ \\
\hline Oil and Soap & $980 \mathrm{mg} / \mathrm{l}$ \\
\hline
\end{tabular}

\section{Results and Discussion}

Generally, there is an electrode position mechanism in the electrocoagulation process due to electrochemical reactions [34]. At the positive side (anode), the dissolution of the anode, which produces metal ions (carbon hydroxide) for coagulation, will reveal that metal oxide is accumulated onto the surface of an electrode. In the meanwhile, the negative side of the metal electrode surface (cathode) is broken down like so many hydrogen bubbles that support moving particles out of the aqueous solution float. After the phase, three layers have been created. A very small, surface-sized waxy flock film, translucent center surfactant, and a large coat of precipitated bottom sludge. The aqueous fluid used in electrical coagulation cells as electrodes turn pure, only after the phase of electrocoagulation. Meanwhile, the treated aqueous solution using iron plates as electrodes become dark green after the electrocoagulation process. It is due to metal corrosion and electrochemical reactions.

\section{1 ct of timeEffe}

The voltage density is kept constant at 15 volts to investigate the effect of the operating time, and the $\mathrm{pH}$ value of the industrial wastewater is modified to 3 . As shown in Figure (3.a), the removal of COD monotonically increased to be $94.93 \%, 27.49 \%$ for aluminum and iron electrode respectively in 30 minutes, and there is no beneficial impact on COD removal for further electro processing of coagulant flocks. On the other hand, removal of oil and grease, achieves a steady value of approximately $90.20 \%$ in 30 min using aluminum electrodes, while in the case of iron electrodes, the removal of oil and grease is slowly rising to $13.27 \%$ in $30 \mathrm{~min}$ as shown in Figure (3.b). The Aluminum electrode showed better performance than iron. therefore, due to the rise in the volume of metal hydroxide coagulant produced in parallel with the increase in time [35], the maximum removal efficiency was achieved. In addition, improved counseling time led to a higher rate of bubble production, which helped to remove lower density Flocs [36-37]. 


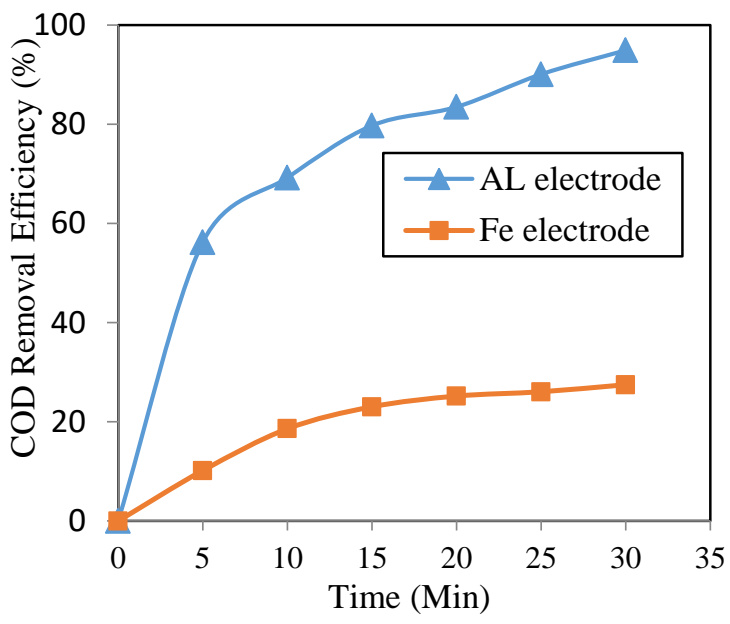

Figure 3.a- Effect of electrocoagulation time on COD removal (Initial COD concentration $19750 \mathrm{mg} / \mathrm{l}$, initial $\mathrm{pH}$ value $3, \mathrm{~V}=15$ volt)

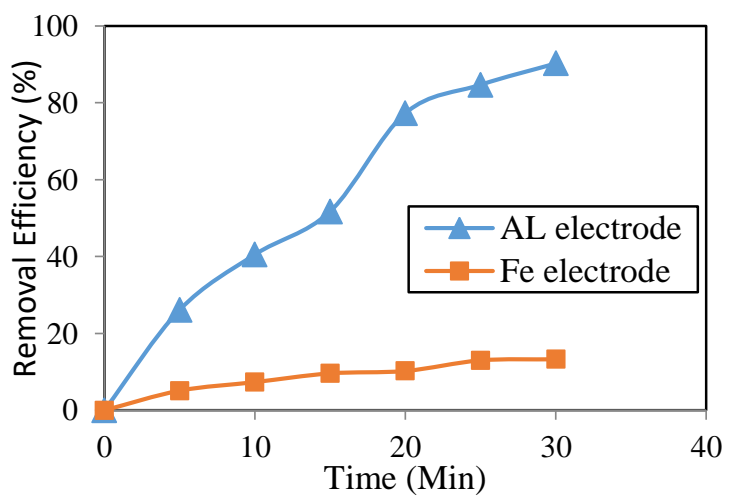

Figure 3.b- Effect of electrocoagulation time on oilgrease removal (initial O\&G concentration $980 \mathrm{mg} / \mathrm{l}$, initial $\mathrm{pH}$ value $3, \mathrm{~V}=15$ volt)

\subsection{Effect of density voltage}

The effects of voltage density are represented in Figures (4.a) and (4.b) with operating time $30 \mathrm{~min}$ and $\mathrm{pH}$ value 3 for $\mathrm{COD}$ and oil-grease removal performance using iron and aluminum electrode materials. In general, both removal efficiencies for both electrode materials are favored by higher current density as observed by many investigators [28-29]. Over (20 volts, 1.6 amperes), COD removal efficiency is $96.3 \%$ for aluminum and $49.37 \%$ for iron. Higher efficiencies are obtained in the case of oil-grease removal; $94,06 \%$ with aluminum and $33.67 \%$ with iron. This is ascribed to the fact that at high current, the amount of aluminum oxidized increased, resulting in a greater amount of precipitate for the removal of pollutants [38]. In the meantime, higher voltage densities (20 volts, 1.6 amperes) above are not economically beneficial. With increasing voltage density, electrical energy consumption increases nonlinearly for both electrode materials, up to (20 volts, 1.6 amperes) due to the strong impact of current density on the cell voltage using various over potentials. On the other hand, according to the laws of Faraday electrolysis, aluminum electrode use is an almost linear function of the voltage density. In the iron case, due to the chemical attack by $\mathrm{H}+$, the consumption values indicate an observable deviation from Faraday's law.

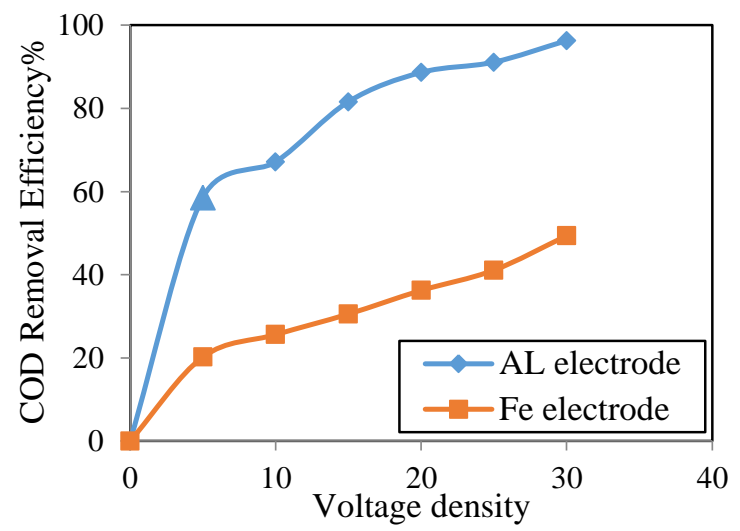

Figure 4.a- Effect of voltage density on COD removal ; ( Initial $\mathrm{pH}$ value 3, Initial COD concentration $19750 \mathrm{mg} / \mathrm{l}$; electrolysis time $30 \mathrm{~min}$

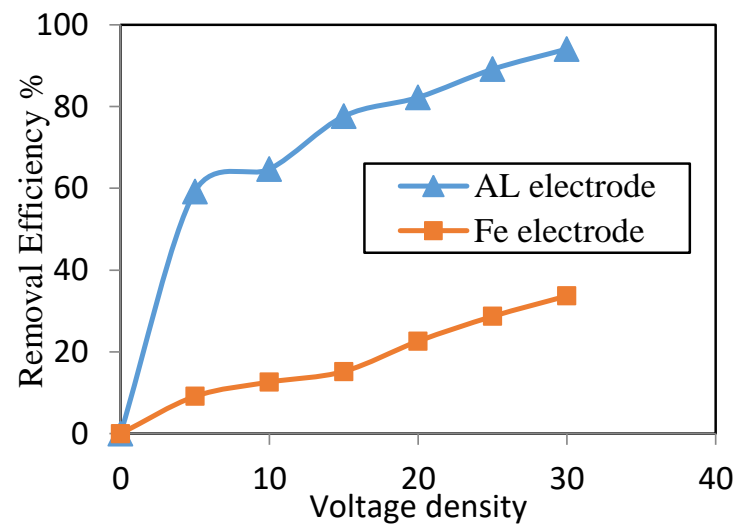

Figure 4.b- Effect of voltage density on oil-grease removal ; (initial $\mathrm{pH}$ value 3 , initial O\&G concentration $980 \mathrm{mg} / \mathrm{l}$; electrolysis time $30 \mathrm{~min}$

\subsection{Effect of initial pH}

The effect of the initial $\mathrm{pH}$ value at a constant current density of $73.33 \mathrm{~A} / \mathrm{m}^{2}$ and EC time of 30 min was investigated on the treatment of oil and soap industrial wastewater. The $\mathrm{pH}$ value is an important operating factor influencing the performance of the electrocoagulation process [27-28-29]. As seen in Figure (5.a), the relationships between the initial and final $\mathrm{pH}$ values of the two electrode materials are different; the effect of the initial $\mathrm{pH}$ value on the 
efficiency of COD removal is seen in Figure. (5.a) in comparative terms. In acidic mediums, high COD removal percent can be obtained for both electrodes, efficiency decreases with increasing $\mathrm{pH}$ value as observed by other investigators because high $\mathrm{pH}$ value will increase $\mathrm{Al}(\mathrm{OH})_{3}$ solubility and lead to the formation of soluble

$$
\mathrm{Al}(\mathrm{OH})_{4}^{-}
$$
, which is useless for

treatment [21-38-39]. The maximum COD removal achieved with the aluminum electrode is $94.93 \%$ and $27.49 \%$ with the iron electrode at $\mathrm{pH}$ value 3 . The effect may be attributed to metal ions which are found in different forms and phases [40]. As seen in Figure (5.b), in the case of oil-grease removal, the aluminum electrode's performance decreases with increasing $\mathrm{pH}$ value, from $90.20 \%$ at $\mathrm{pH}$ value 3 to $47.96 \%$ at $\mathrm{pH}$ value 11 . Also, as the $\mathrm{pH}$ value increase, the efficiency of iron electrodes decreased, from $13.26 \%$ at $\mathrm{pH}$ value 3 to $8.5 \%$ at $\mathrm{pH}$ value 11 . The removal of oil-grease from industrial wastewater is carried out according to various complex mechanisms; electrophoretic destabilization by the electric field and by electro-generated Fe or Al salts may also occur in addition to adsorption or trapping in metal hydroxide flocks and improving EC removal efficiency.

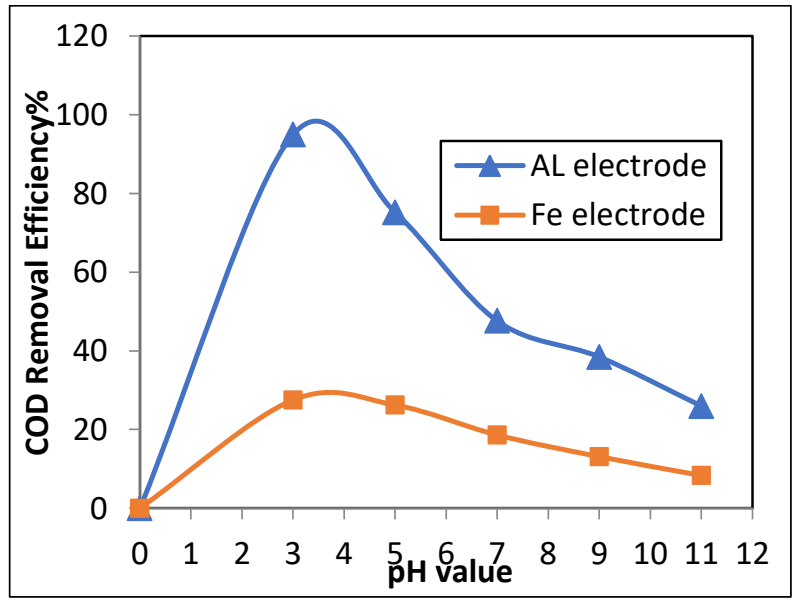

Figure 5.a- Effect of initial $\mathrm{pH}$ value on COD removal

(initial COD concentration $19750 \mathrm{mg} / \mathrm{l}$; volt=15 v).

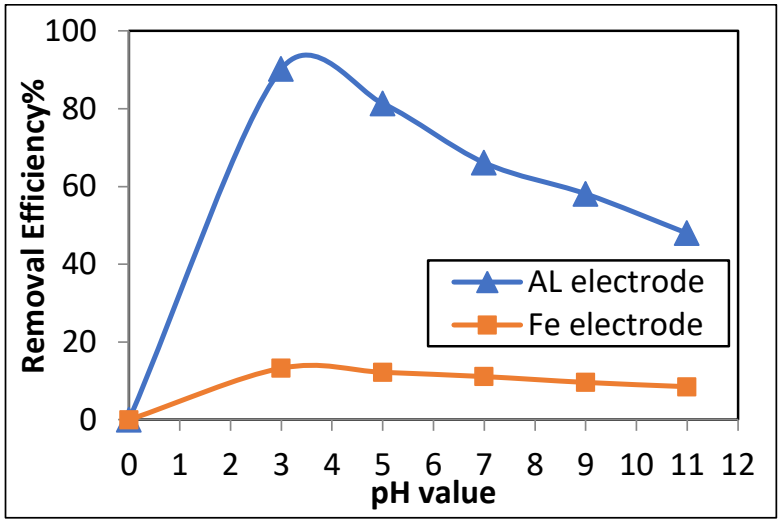

Figure 5.b- Effect of initial pH value on oil- grease removal

(initial O\&G concentration $980 \mathrm{mg} / \mathrm{l}$; volt=15 v)

\subsection{Energy consumption of electrocoagulation process}

The total electricity of the process is measured and the adjustments of the $\mathrm{pH}$ value are compared before and After EC. measurements were made for the Aluminum and iron electrodes. The measurement is performed in such a way that the $\mathrm{pH}$ value of industrial wastewater is 3 and with an optimal reaction time of 30 minutes. The operating cost of electrocoagulation can be given as the following equations according to the steps of this study.

$E C\left(K W h / m^{3}\right)=\frac{V * i * t_{E C}}{V}$

$K W h / k g$ COD removal efficiency $=\frac{V * i * t_{E C} * 1000}{V *(\mathrm{ci} * \mathrm{COD})}$

Where :( $\mathrm{V}$ is applied voltage (volt), I is current intensity (A), $\mathrm{t}_{\mathrm{EC}}$ is operating time (hour), $\mathrm{v}$ is a volume (liter) of the solution, $c_{i}$ is initial COD concentration $(\mathrm{mg} / \mathrm{l}), \% \mathrm{COD}$ is $\mathrm{COD}$ removal efficiency).

As shown in Figure (6), the energy consumption was increased from 0.16 to $1.68 \mathrm{KWh} / \mathrm{kg}$ COD removal for the Aluminum electrode and from 0.47 to 3.04 $\mathrm{KWh} / \mathrm{kg}$ COD removal for the iron electrode with an increase in applied voltage from 5 to 15 volts respectively. The results of energy have been registered in the table (2). 
Table 2- Energy consumption at various applied voltage for EC system

\begin{tabular}{|c|c|c|c|c|c|c|c|c|}
\hline $\begin{array}{c}\text { Applied } \\
\text { voltage } \\
\text { (volt) }\end{array}$ & $\begin{array}{l}\text { current } \\
\text { (Ampere) }\end{array}$ & $\begin{array}{l}\text { Time } \\
(\mathrm{min})\end{array}$ & $\begin{array}{c}\text { Initial } \\
\text { Conc. of } \\
\text { COD } \\
(\mathrm{mg} / \mathrm{l} .)\end{array}$ & $\begin{array}{c}\text { COD } \\
\text { Removal } \\
\text { for (AL }(\%))\end{array}$ & $\begin{array}{c}\text { COD } \\
\text { Removal } \\
\text { for }(\%) \\
(\mathrm{Fe})\end{array}$ & $\begin{array}{c}\text { EC } \\
\mathrm{Kwh} / \mathrm{m}^{3}\end{array}$ & $\begin{array}{c}\mathrm{EC} \\
(\mathrm{KWh} / \mathrm{kg} \\
\mathrm{COD} \%) \text { for } \\
(\mathrm{AL})\end{array}$ & $\begin{array}{c}\mathrm{EC} \\
(\mathrm{KWh} / \mathrm{kg} \\
\mathrm{COD} \%) \\
\text { for }(\mathrm{Fe})\end{array}$ \\
\hline 5 & 0.3 & 30 & \multirow{3}{*}{19750} & 47.54 & 10.16 & 1.5 & 0.16 & 0.47 \\
\hline 10 & 0.5 & 30 & & 52.21 & 20.12 & 5 & 0.48 & 1.26 \\
\hline 15 & 1.1 & 30 & & 94.94 & 27.49 & 16.5 & 0.87 & 3.04 \\
\hline
\end{tabular}

The energy is directly associated with the voltage applied. This indicates that the increase in applied voltage has an inverse effect on current and electrode efficiency. The optimum value of the applied voltage was obtained from this experimental condition at 15 volts.

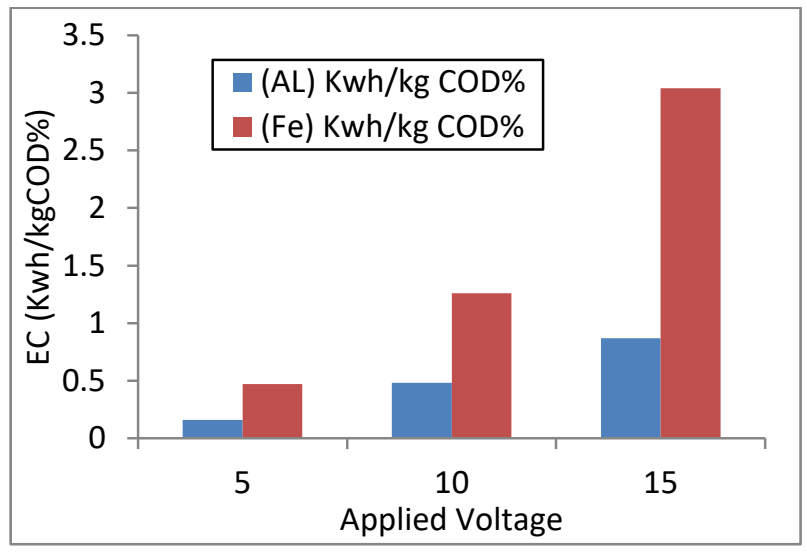

Figure 6- Effect of applied voltage on energy

Consumption: initial COD concentration $=19750 \mathrm{mg} / \mathrm{l}$, volume of solution $=500 \mathrm{mg} / \mathrm{l}$, initial $\mathrm{pH}$ value 3

\section{Conclusions}

This study showed that the electrocoagulation process has the potential to remove pollutants effluent from oil and soap industrial wastewater as the results showed that percentage removal of oil-grease and COD from the solution using aluminum as electrodes always reached more than removal using iron as electrodes for all three effects in the electrocoagulation process. It can be concluded that the electrocoagulation method is reliable and efficient for oil and soap industrial wastewater removal which is specially designed for initial COD and O\&G concentration $19750 \mathrm{mg} / \mathrm{l}, 980 \mathrm{mg} / \mathrm{l}$ respectively. An Aluminum electrode is an effective approach for treating industrial oil and soap wastewater using electrocoagulation process and performs better than iron electrode in reducing the COD and O\&G; at low initial $\mathrm{pH}$ value, such as 3 , and current density of $73.33 \mathrm{~A} / \mathrm{m}^{2}$ are perfect able for having a high COD and $\mathrm{O} \& \mathrm{G}$ removal efficiency $94.93 \%, 90.20 \%$ respectively in $30 \mathrm{~min}$. Energy consumption was increased with increasing Current intensity. Since the current intensity is the main variable in controlling the Performance of the electrocoagulation. On the other hand, iron electrode is not effective at low $\mathrm{pH}$ value at $\mathrm{pH}$ value $3 \mathrm{COD}$ and $\mathrm{O} \& \mathrm{G}$ removal efficiency equal $27.49 \%, 13.27 \%$ respectively.

\section{References}

[1] Hildenbrand, Z.L., Carlton Jr., D.D., Fontenot, B.E., Meik, J.M., Walton, J.L., Thacker, J.B., Korlie, S., Shelor, C.P., Kadjo, A.F., Clark, A., Usenko, S., Hamilton, J.S., Mach, P.M., Verbeck Iv, G.F., Hudak, P., Schug, K.A., 2016. Temporal variation in groundwater quality in the Permian Basin of Texas, a region of increasing unconventional oil and gas development. Sci. Total Environ. 562, 906-913.

[2] Rengasamy, R.S., Das, D., Praba Karan, C., 2011. Study of oil sorption behavior of filled and structured fiber assemblies made from polypropylene, kapok and milkweed fibers. J. Hazard. Mater. 186, 526-532.

[3] Kajitvichyanukul, P., Hung, Y.T., Wang, L., 2011. In: Wang, L., Chen, J., Hung, Y.T., Shammas, N. (Eds.), Membrane and Desalination Technologies. Humana Press, pp. 639-668.

[4] Hussein, M., Amer, A.A., Sawsan, I.I., 2008. Oil spill sorption using carbonized pith bagasse 
1. Preparation and characterization of carbonized pith bagasse. J. Anal. Appl. Pyrolysis 82, 205-211.

[5] Srinivasan, A., Viraraghavan, T., 2010. Oil removal from water using biomaterials. Bioresour. Technol. 101, 6594-6600.

[6] Suzuki, Y., Maruyama, T., 2005. Removal of emulsified oil from water by coagulation and foam separation. Sep. Sci. Technol. 40, 34073418.

[7] Bratskaya, S., Avramenko, V., Schwarz, S., Philippova, I., 2006. Enhanced flocculation of oilin-water emulsions by hydrophobically modified chitosan derivatives. Colloids Surf. A Physicochem. Eng. Asp. 275, 168-176.

[8] Adebajo, M.O., Frost, R.L., Kloprogge, J.T., Carmody, O., Kokot, S., 2003. Porous materials for oil spill cleanup: a review of synthesis and absorbing properties. J. Porous. Mater. 10, 159-170.

[9] Andreozzi, R., Caprio, V., Insola, A., Marotta, R., Sanchirico, R., 2000. Advanced oxidation processes for the treatment of mineral oilcontaminated wastewaters. Water Res. 34, 620628.

[10] Ezzati, A., Gorouhi, E., Mohammadi, T., 2005. Separation of water in oil emulsions using microfiltration. Desalination 185, 371382Ezzati, A., Gorouhi, E., Mohammadi, T., 2005. Separation of water in oil emulsions using microfiltration. Desalination 185, 371-382.

[11] Husveg, T., Rambeau, O., Drengstig, T., Bilstad, T., 2007. Performance of a deoiling hydrocyclone during variable flow rates. Miner. Eng. 20, 368-379.

[12] Wilkinson, D., Waldie, B., Mohamad nor, M.I., Yen Lee, H., 2000. Baffle plate configurations to enhance separation in horizontal primary separators. Chem. Eng. J. 77, 221-226.

[13] Arsand, D.R., Kümmerer, K., Martins, A.F., 2013. Removal of dexamethasone from aqueous solution and hospital wastewater by electrocoagulation. Sci. Total Environ. 443, 351-357.
[14] Nguyen, D.D., Ngo, H.H., Guo, W., Nguyen, T.T., Chang, S.W., Jang, A., Yoon, Y.S., 2016. Can electrocoagulation process be an appropriate technology for phosphorus removal from municipal wastewater? Sci. Total Environ. 563-564, 549-556.

[15] Wang, Y., Lin, H., Jin, F., Niu, J., Zhao, J., Bi, Y., Li, Y., 2016. Electrocoagulation mechanism of perfluorooctanoate (PFOA) on a zinc anode: influence of cathodes and anions. Sci. Total Environ. 557-558, 542-550.

[16] Un, U.T., Koparal, A.S., Ogutveren, U.B., 2009. Electrocoagulation of vegetable oil refinery wastewater using aluminum electrodes. J. Environ. Manag. 90, 428-433.

[17] Bensadok, K., El Hanafi, N., Lapicque, F., 2011. Electrochemical treatment of dairy effluent using combined $\mathrm{Al}$ and $\mathrm{Ti} / \mathrm{Pt}$ electrodes system. Desalination 280, 244-251.

[18] P.K. Holt, G.W. Barton, C.A. Mitchell, The future for electrocoagulation as a localised water treatment technology, Chemosphere 59 (2005) 355-367.

[19] N. Daneshvar, H. Ashassi-Sorkhabi, A. Tizpar, Decolorization of orange II by electrocoagulation method, Sep. Purif. Technol. 31 (2003) 153-162.

[20] I. Zongo, J.-P. Leclerc, H. Amadou Maïga, J. Wéthé, F. Lapicque, Removal of hexavalent chromium from industrial wastewater by electrocoagulation: a comprehensive comparison of aluminium and iron electrodes, Sep. Purif. Technol. 66 (2009) 159-166.

[21] C.H.A. Moreno, D.L. Cocke, J.A.G. Gomes, P. Morkovsky, J.R. Parga, E. Peterson, C. Garcia, Electrochemical reactions for electrocoagulation using iron electrodes, Ind. Eng. Chem. Res. 2282-2275 (2009).

[22] C.H.A. Moreno, D.L. Cocke, J.A.G. Gomes, P. Morkovsky, J.R. Parga, E. Peterson, C. Garcia, Electrochemical reactions for electrocoagulation using iron electrodes, Ind. Eng. Chem. Res. (2009) 2275-2282.

[23] N. Mameri, A.R. Yeddou, H. Lounici, D. Belhocine, H. Grib, B. Bariou, Defluoridation of septentrional Sahara water of North Africa by 
electrocoagulation process using bipolar aluminium electrodes, Water Res. 32 (1998) 1604-1612.

[24] G. Mouedhen, M. Feki, M. De Petris Wery, H.F. Ayedi, Behavior of aluminum electrodes in electrocoagulation process, J. Hazard. Mater. 150 (2008) 124-135.

[25] M. Asselin, P. Drogui, H. Benmoussa, J.-F. Blais, Effectiveness of electrocoagulation process in removing organic compounds from slaughterhouse wastewater using monopolar and bipolar electrolytic cells, Chemosphere 72 (2008) 1727-1733.

[26] C.Y. Hu, S.L. Lo, W.H. Kuan, Y.D. Lee, Removal of fluoride from semiconductor wastewater by electrocoagulation-flotation, Water Res. 39 (2005) 895-901.

[27] M. Kobya, O.T. Can, M. Bayramoglu, Treatment of textile wastewaters by electrocoagulation using iron and aluminum electrodes, J. Hazard. Mater. 100 (2003) 163178.

[28] N. Adhoum, L. Monser, Decolourization and removal of phenolic compounds from olive mill wastewater by electrocoagulation, Chem. Eng. Process. 43 (2004) 1281-1287.

[29] X. Chen, G. Chen, P.L. Yue, Electrocoagulation and electroflotation of restaurant wastewater, J. Environ. Eng-ASCE 126 (9) (2000) 858-863.

[30] F. Shen, X. Chen, P. Gao, G. Chen, Electrochemical removal of fluoride ions from industrial wastewaters, Chem. Eng. Sci. 58 (2003) 987-993.

[31] M.-F. Pouet, A. Grasmick, Urban wastewater treatment by electrocoagulation and flotation, Water Sci. Technol. 31 (1995) 275-283.

[32] J.R. Parga, D.L. Cocke, J.L. Valenzuela, J.A. Gomes, M. Kesmez, G. Irwin, H. Moreno, M. Weir, Arsenic removal via electrocoagulation from heavy metal contaminated groundwater in La Comarca Lagunera México, J. Hazard. Mater. 124 (2005) 247-254.

[33] Al Aji, B., Yavuz, Y., Koparal, A.S., 2012. Electrocoagulation of heavy metals containing model wastewater using monopolar iron electrodes. Sep. Purif. Technol. 86, 248e254

[34] Zainal Abidin, M. S., Shahjahan, Mahmood, M. R., \& Hashim, A. M. 2015. Electrodeposited germanium on silicon substrate using a mixture of germanium tetrachloride and propylene glycol. Jurnal Teknologi. 1: 77-82

[35] Zongo, I., Hama, A., Wéthé, J., Valentin, G., Leclerc, J., Paternotte, G., \& Lapicque, F. 2009. Electrocoagulation for the treatment of textile wastewaters with $\mathrm{Al}$ or $\mathrm{Fe}$ electrodes: Compared variations of COD levels, turbidity and absorbance. Journal of Hazardous 76 -Materials. 169: 70.

[36] Chen, G. 2004. Electrochemical technologies in wastewater treatment. Separation and Purification Technology. 38: $11-41$.

[37] Mollah, M.Y.A., Morkovsky, P., Gomes, J.A.G., Kesmez, M., Parga, J., and Cocke, D.L. 2004. Fundamentals, present and future perspectives of electrocoagulation. Journal of Hazardous Materials. B114: 199 - 210.

[38] N. Adhoum, L. Monser, N. Bellakhal, J.E. Belgaied, Treatment of electroplating wastewater containing $\mathrm{Cu} 2+, \mathrm{Zn} 2+$ and $\mathrm{Cr}$ (VI) by electrocoagulation, J. Hazard. Mater. B 112 207 (2004)-213

[39] P.H. Holt, G.W. Barton, M. Wark, A.A. Mitchell, A quantitative comparison between chemical dosing and electrocoagulation, Colloids Surf. A: Physicochem. Eng. Aspects 211 (2002) 233-248.

[40] Drogui, Patrick, Mélanie Asselin, Satinder K. Brar, Hamel Benmoussa, and Jean-François Blais. 2008. "Electrochemical Removal of Pollutants from Agro-Industry Wastewaters." Separation and Purification Technology 61 (3): 301-310. 